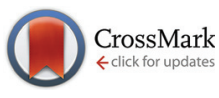

Cite this: Biomater. Sci., 2016, 4, 1412

Received 25th April 2016, Accepted 2nd August 2016

DOI: $10.1039 / \mathrm{c} 6 \mathrm{bm} 00287 \mathrm{k}$

www.rsc.org/biomaterialsscience

\section{Synthesis, characterization and in vitro biocompatibility assessment of a novel tripeptide hydrogelator, as a promising scaffold for tissue engineering applications $\uparrow$}

\author{
Tihomir Pospišil, ${ }^{\mathrm{a}}$ Lejla Ferhatović Hamzić, ${ }^{\mathrm{b}}$ Lada Brkić Ahmed, ${ }^{\mathrm{b}}$ Marija Lovrić, ${ }^{\mathrm{b}}$ \\ Srećko Gajović*b and Leo Frkanec ${ }^{* a}$
}

We have synthesized and characterized a self-assembling tripeptide hydrogelator AC-L-Phe-L-Phe-L-Ala- $\mathrm{NH}_{2}$. A series of experiments showed that the hydrogel material could serve as a stabile and biocompatible physical support as it improves the survival of HEK293T cells in vitro, thus being a promising biomaterial for use in tissue engineering applications.

Hydrogel biomaterials, closely mimicking the three-dimensional extracellular matrix (ECM), are considered to be ideal materials for cell and tissue scaffolding applications due to their biocompatibility, hydrophilic character, mechanical properties (lower micromechanical modulus) and structural diversity. ${ }^{1}$ The dynamic nature of the noncovalent hydrogel fibril network allows the hydrogel material to spontaneously adjust to the surrounding environment and the cells to migrate through the matrix compared to covalent hydrogels whose pores are chemically constrained and relatively inflexible. ${ }^{2}$ Short self-assembling peptides made from natural amino acids with alternating hydrophobic and hydrophilic amino acids undergo spontaneous self-assembly into nanofiber hydrogel scaffolds under physiological conditions. ${ }^{3}$ The weak noncovalent interactions such as hydrogen bonding, $\pi-\pi$ stacking, electrostatic and van der Waals interactions are mainly responsible for the self-assembly process. These scaffolds consisting of nanofiber networks surround cells in a manner similar to the ECM and the process is triggered by the addition of cell suspensions to the aqueous solutions. ${ }^{4}$ Ultrashort peptide hydrogels made of two or three amino acids are especially suitable for biomedical applications because they are costeffective, simple to prepare and accessible to production on a

\footnotetext{
${ }^{a}$ Laboratory for Supramolecular Chemistry, Division of Organic Chemistry and Biochemistry, Ruđer Bošković Institute, Bijenička 54, 10000 Zagreb, Croatia. E-mail: frkanec@irb.hr

${ }^{b}$ Croatian Institute for Brain Research, University of Zagreb, School of Medicine, Šalata 12, 10000 Zagreb, Croatia.E-mail: srecko.gajovic@hiim.hr

$\dagger$ Electronic supplementary information (ESI) available: Synthesis and spectroscopic characterization of hydrogel. See DOI: 10.1039/c6bm00287k
}

large-scale. ${ }^{5}$ A large number of such scaffolds described in the literature require the use of synthetic protecting groups (such as Fmoc, naphthalene, etc.) and/or small amounts of organic solvents (e.g. DMSO) needed for peptide dissolution and selfassembly. ${ }^{6}$ However, neither of these approaches are suitable for biomedical applications because it is advisable to avoid toxic organic solvents and some aromatic molecules (e.g. Fmoc) when dealing with cells as it may lead to reduced cell viability in vitro. ${ }^{7}$ Continuing the long lasting research of the IRB group on supramolecular gelation ${ }^{8}$ we developed a new type of self-assembling tripeptide hydrogel Ac-L-Phe-L-Phe-LAla- $\mathrm{NH}_{2}$ for use in tissue engineering approaches. Ac-L-Phe-LPhe-L-Ala- $\mathrm{NH}_{2}$ self-assembles at physiological $\mathrm{pH}$ without the need for any organic solvent. This tripeptide derivative contains an aromatic diphenylalanine moiety (Phe-Phe) as a minimalistic building block to drive the self-assembly of short peptides into nanostructures and hydrogels of high stability. ${ }^{9}$

The tripeptide hydrogelator Ac-L-Phe-L-Phe-L-Ala- $\mathrm{NH}_{2}$ was prepared in five synthetic steps (Scheme $\mathrm{S}-1 \dagger$ ). The starting Boc-L-Phe-L-Ala-OMe dipeptide was prepared from commercially available reagents by a procedure described in the literature. ${ }^{10}$ Boc-deprotection was achieved using $\mathrm{TFA}^{11}$ to give an unprotected dipeptide L-Phe-L-Ala-OMe. L-Phe-L-Ala-OMe was then coupled to an activated Boc-protected phenylalanine succinimide ester to give the Boc-L-Phe-L-Phe-L-Ala-OMe tripeptide. After Boc-deprotection, the tripeptide was acetylated with acetyl chloride to give the acetyl tripeptide methyl ester, Ac-L-Phe-L-Phe-L-Ala-OMe. In the last step, ammonolysis of the acetyl tripeptide methyl ester with dry ammonia in methanol resulted in a final product, Ac-L-Phe-L-Phe-L-Ala- $\mathrm{NH}_{2}$ in 98\% yield.

Minimal gelation concentration (MGC) was the lowest concentration of the gelator in the solution that could form a hydrogel. Ac-L-Phe-L-Phe-L-Ala- $\mathrm{NH}_{2}$ can gel saline at a minimum gelation concentration of $0.7 \%, \mathrm{w} / \mathrm{v}$. The tripeptide hydrogel maintains a stable self-supporting structure under physiological conditions over weeks at a very low concentration of $2.64 \mathrm{mg} \mathrm{ml}^{-1}$ (Fig. 1). 

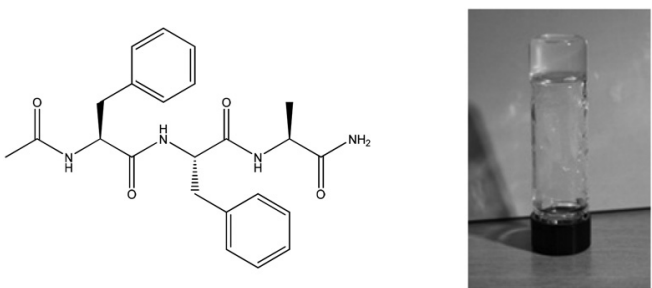

Fig. 1 Chemical structure of hydrogelator and a picture of the hydrogel formed by Ac-L-Phe-L-Phe-L-Ala- $\mathrm{NH}_{2}$ in saline $(\mathrm{pH}=6.12$, $2.64 \mathrm{mg} \mathrm{ml}^{-1}$ ).

Transmission Electron Microscopy (TEM) images of the nanofibrous hydrogel network show the presence of a mixture of fibers and straight ribbons with diameters in the range of 50-500 $\mathrm{nm}$ and lengths in the range of micrometers (Fig. 2).

FTIR and NMR investigation pointed toward the cross- $\beta$ structure type of hydrogen bonding of the tripeptide in the gel aggregates. ${ }^{12}$ Intramolecular hydrogen bonding and noncovalent interactions between molecules of hydrogelators are responsible for the formation of the $3 \mathrm{D}$ gel network. ${ }^{13}$

The mechanical properties of the tripeptide hydrogel were investigated by basic rheological measurements, in order to determine the suitability of the hydrogel for use in tissue engineering applications. The storage modulus $\left(G^{\prime}\right)$ is 6 fold greater than the loss modulus $\left(G^{\prime \prime}\right)$ under constant strain at $2 \%$ (Fig. S-12†) which indicates the viscoelastic properties of the proposed hydrogel biomaterial. The rheological studies confirm that our hydrogel satisfies criteria similar to other small peptide hydrogels described in the literature. ${ }^{14,15}$

The tripeptide hydrogel is transparent and therefore suitable for microscopy analysis. A series of experiments have been performed in order to assess in vitro biocompatibility of the novel material.

Human embryonic kidney cells (HEK293T) have been used as a reproducible model cell line and were cultured following established proliferation protocols. These cells were found to be a simple model cell line used for hydrogel-based biomaterial cytocompatibility evaluations. ${ }^{16}$ In addition, they show

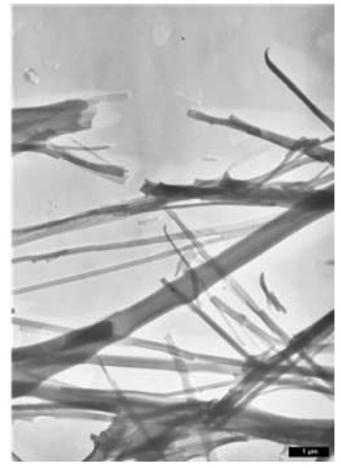

a)

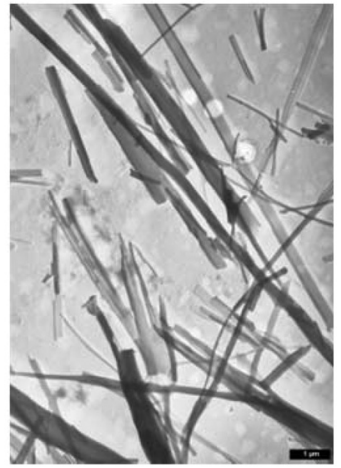

b)
Fig. 2 TEM images of the tripeptide hydrogel network (a) PWK-stained and (b) Pd-shadowed (saline, $c=2.64 \mathrm{mg} \mathrm{ml}^{-1}$ ). properties of immature neurons, thus being suitable for biological screening in neural tissue engineering. ${ }^{17}$ HEK293T cells were encapsulated in vitro within a three-dimensional network of nanofibers formed by self-assembly of peptide molecules. The self-assembly was triggered by mixing cell suspensions in media with a physiological saline solution of the peptide molecules and the cells survived the growth of the nanofibers around them. The results of the PicoGreen assay showed that HEK293T cells proliferate when cultured within Ac-L-Phe-L-Phe-L-Ala- $\mathrm{NH}_{2}$ hydrogel fibers, as the total cell number was significantly higher on day 5 compared to day 0 (Fig. 3).

As expected, the total cell number also increased significantly in two positive control groups (Matrigel and medium) and decreased in a negative control group (latex rubber). Surprisingly, the cell number was significantly higher in Ac-L-PheL-Phe-L-Ala- $\mathrm{NH}_{2}$ hydrogel samples compared to Matrigel on the 5 th day $(549.20 \pm 25.17$ vs. $296.40 \pm 92.11, t$-test, $p<0.05)$. The novel supramolecular hydrogel was shown to be effective in enhancing cell proliferation up to 5 days of culturing. In addition, the obtained results reveal the advantages of the novel tripeptide hydrogel compared to Matrigel. A small proportion of the cells precipitated during this time at the bottom of the wells in both Ac-L-Phe-L-Phe-L-Ala- $\mathrm{NH}_{2}$ hydrogel and Matrigel, but the majority of the cells remained in gels and formed agglomerates. Matrigel was previously proved to be a suitable scaffolding support for culturing cells. Being a naturally-derived material, Matrigel cannot match requirements for reproducibility, but this can be overcome by the use of synthetic materials like the Ac-L-Phe-L-Phe-L-Ala- $\mathrm{NH}_{2}$ hydrogel.

Viability was assessed with the LIVE/DEAD assay and was expressed as the percentage of living cells in the total cell number. Viability of HEK293T cells was high in all samples except in latex rubber, where no viable cells were observed on day 5 (Fig. 4-6).

There were no significant differences in the percentage of live cells between HEK293T cells cultured with Matrigel $(82.7 \pm 5.79 \%)$, medium (83.78 $\pm 2.37 \%)$ or Ac-L-Phe-LPhe-L-Ala- $\mathrm{NH}_{2}$ hydrogel $(89.78 \pm 1.43 \%)$. Morphology of the HEK293T cells transfected with tubulin-mCherry grown in the

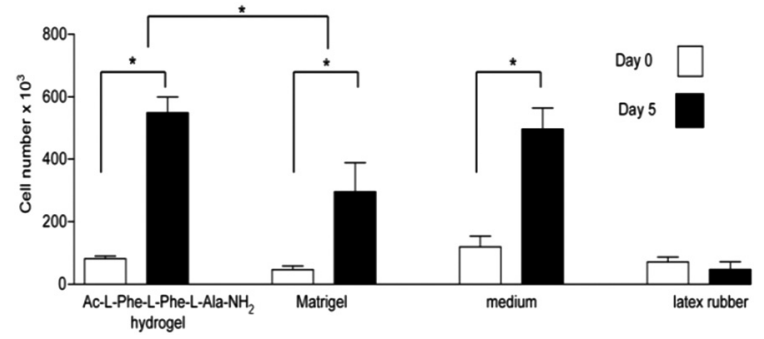

Fig. 3 HEK293T cells proliferate well encapsulated within the AC-LPhe-L-Phe-L-Ala- $\mathrm{NH}_{2}$ hydrogel scaffold. HEK293T cell number was determined using Quant-iTTM PicoGreen ${ }^{\mathrm{T}}$ dsDNA Kit on day 0 and 5 for cells grown in the peptide hydrogel scaffold, Matrigel, on latex or within medium only. Results represent mean \pm SD of 4 independent experiments performed in triplicate. $p<0.05$. 


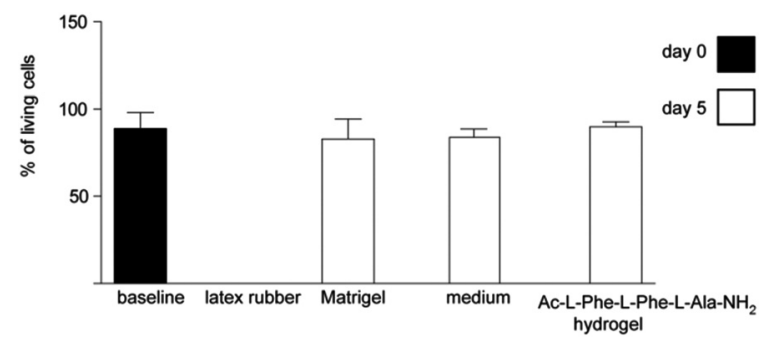

Fig. 4 HEK293T cells show high viability encapsulated within the Ac-LPhe-L-Phe-L-Ala- $\mathrm{NH}_{2}$ hydrogel scaffold. Percentage of live cells was determined using LIVE/DEAD viability/cytotoxicity assay on day 0 and 5 for cells encapsulated within the peptide hydrogel scaffold, or grown on Matrigel, latex or in medium only. Results are shown as percentage of live cells and represent mean \pm SD of 4 independent experiments performed in triplicate.
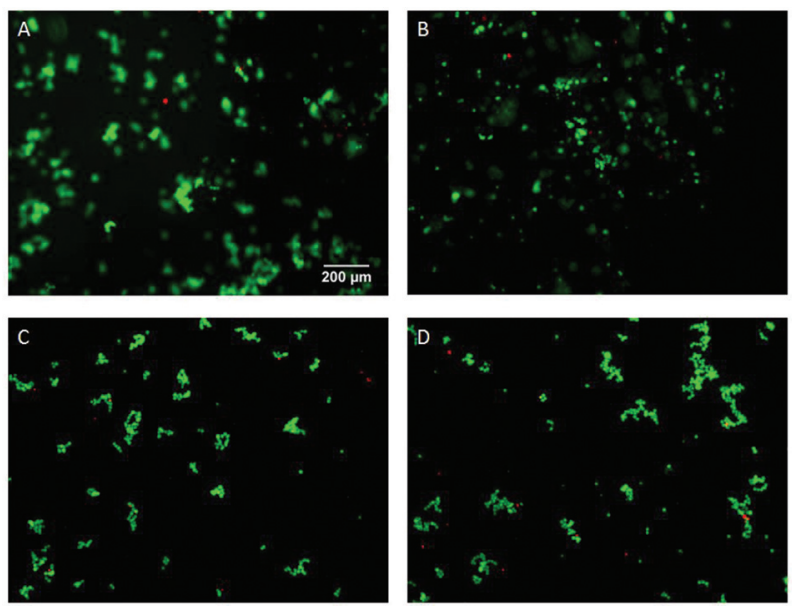

Fig. 5 HEK293T cells in: (A) AC-L-Phe-L-Phe-L-Ala- $\mathrm{NH}_{2}$, (B) Matrigel, (C) medium, (D) latex. On the 0 day of the experiment. Live cells are green, and dead cells are red. Magnification 10x, scale bar applies to all.
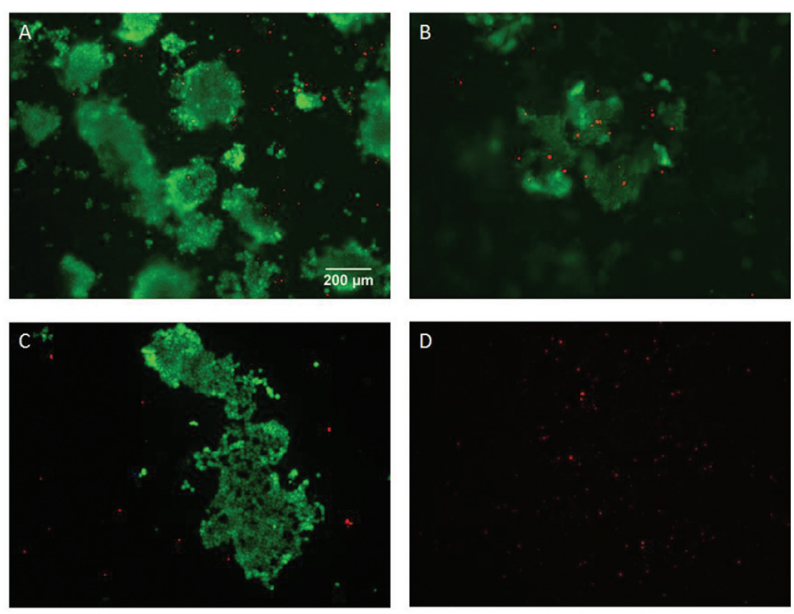

Fig. 6 HEK293T cells in: (A) AC-L-Phe-L-Phe-L-Ala- $\mathrm{NH}_{2}$, (B) Matrigel, (C) medium, (D) latex. On the $5^{\text {th }}$ day of the experiment. Live cells are green, and dead cells are red. Magnification 10x, scale bar applies to all.
Ac-L-Phe-L-Phe-L-Ala- $\mathrm{NH}_{2}$ hydrogel compared to the cells grown in medium was observed by using a confocal microscope. The cells grown in the Ac-L-Phe-L-Phe-L-Ala- $\mathrm{NH}_{2}$ hydrogel form aggregates that are visible in a range of different $z$ planes, while the cells grown in medium adhere to the well surface and are all visible in the same $z$ planes (Fig. S-13† and Fig. 7). In addition, the cells were visualised under bright light, and the cells belonging to one aggregate within the hydrogel could be clearly distinguished from the cells grown in other aggregates, being the only ones in the clear focus of the microscope, while the others appeared blurred (Fig. 8).

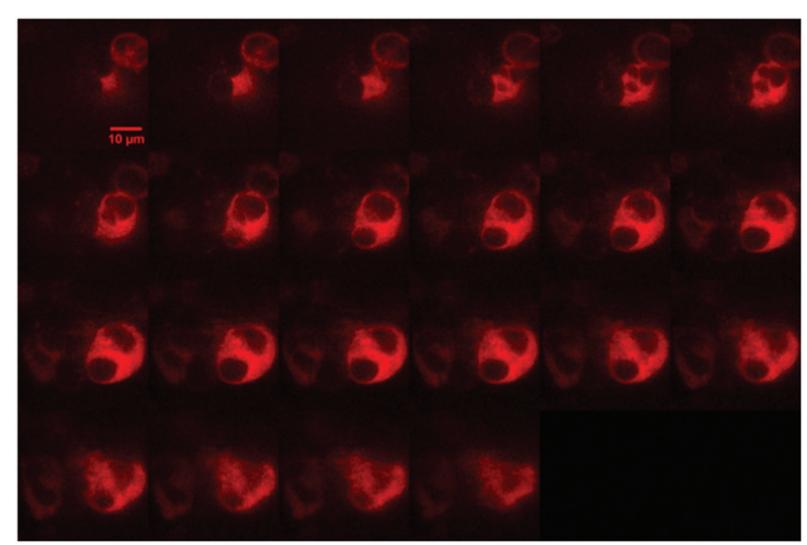

Fig. 7 HEK293T cells transfected with tubulin-mCherry, grown in AC-LPhe-L-Phe-L-Ala- $\mathrm{NH}_{2}$ hydrogel and observed under a confocal microscope after $72 \mathrm{~h}$. Cells formed aggregates within the hydrogel and are visible in different $z$ planes. Magnification $100 \times$, scale bar applies to all.
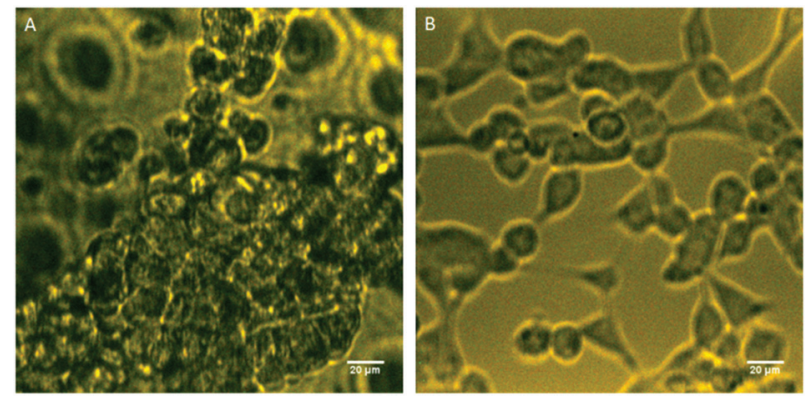

Fig. 8 HEK293T cells grown in: (A) Ac-L-Phe-L-Phe-L-Ala- $\mathrm{NH}_{2}$ hydrogel and (B) medium and observed $72 \mathrm{~h}$ after encapsulation. Bright field microscopy shows that cells form aggregates within the hydrogel, while cells grown in medium adhered to the surface. Magnification 20x.

\section{Conclusions}

In this study we have developed a new type of noncovalent supramolecular self-assembling tripeptide hydrogel, Ac-L-PheL-Phe-L-Ala- $\mathrm{NH}_{2}$ and evaluated its physicochemical and biological properties in vitro. We found that the tripeptide Ac-L-Phe-LPhe-L-Ala- $\mathrm{NH}_{2}$ self-assembles into nanofiber hydrogel scaffolds 
under physiological conditions. The obtained material was established as a stabile and biocompatible physical support for HEK293T cells in vitro. Ac-L-Phe-L-Phe-L-Ala- $\mathrm{NH}_{2}$ efficiently supported survival and promoted proliferation of HEK293T cells encapsulated within a three-dimensional nanofiber network. Furthermore, these results suggest the need for further evaluation of in vitro biocompatibility and bioactivity of this tripeptide on neural stem cells upon encapsulation in order to investigate for possible tissue engineering application.

\section{Acknowledgements}

This work was supported by the Ministry of Science, Education and Sports of the Republic of Croatia, the Croatian Science Foundation (HRZZ project IP-11-2013-7387), and EU FP7 GlowBrain project (REGPOT-2012-CT2012-316120). The authors thank Dr Hrvoje Banfić (Croatian Institute for Brain Research, University of Zagreb, School of Medicine, Zagreb) for providing HEK293T cells. We greatly acknowledge the access to the equipment in possession of the University of Rijeka within the project RISK "Development of University of Rijeka campus laboratory research infrastructure", financed by the European Regional Development Fund (ERDF) supported by a EU FP7 grant, and particularly Dr Karlo Wittine and Dr Uroš Anđelković for providing HRMS spectra.

\section{Notes and references}

1 S. Woerly, Biomaterials, 1993, 14, 1056; A. Birgersdotter, R. Sandberg and I. Ernberg, Semin. Cancer Biol., 2005, 15, 405; M. R. Hynd, J. N. Turner and W. Shain, J. Biomater. Sci., Polym. Ed., 2007, 18, 1223; D. R. Nisbet, K. E. Crompton, M. K. Horne, D. I. Finkelstein and J. S. Forsythe, J. Biomed. Mater. Res., Part B, 2008, 87B, 251; Y. Nagai, H. Yokoi, K. Kaihara and K. Naruse, Biomaterials, 2012, 33, 1044; R. Dong, Y. Pang, Y. Su and X. Zhu, Biomater. Sci., 2015, 3, 937; Z. Yu, Z. Cai, Q. Chen, M. Liu, L. Ye, J. Ren, W. Liao and S. Liu, Biomater. Sci., 2016, 4, 365.

2 S. Zhang, Nat. Biotechnol., 2003, 21, 1171; L. A. Estroff and A. D. Hamilton, Chem. Rev., 2004, 104, 1201; F. Gelain, D. Bottai, A. Vescovi and S. Zhang, PLoS One, 2006, 1(1), e119, DOI: 10.1371/journal.pone.0000119; L. Yu and J. Ding, Chem. Soc. Rev., 2008, 37, 147; F. Gelain, D. Bottai, A. Vescovi, S. Zhang, M. W. Tibbitt and K. S. Anseth, Biotechnol. Bioeng., 2009, 103, 655; G. Orive, E. Anitua, J. L. Pedraz and D. F. Emerich, Nat. Rev. Neurosci., 2009, 10, 682; W. T. Truong, Y. Su, J. T. Meijer, P. Thordarson and F. Braet, Chem. - Asian J., 2011, 6, 30.

3 H. Yokoi, T. Kinoshita and S. Zhang, Proc. Natl. Acad. Sci. U. S. A., 2005, 102, 8414; E. Garreta, E. Genove, S. Borros and C. E. Semino, Tissue Eng., 2006, 12, 2215; A. L. Sieminski, A. S. Was, G. Kim, G. Haiyan and R. D. Kamm, Cell Biochem. Biophys., 2007, 49, 73; M. Zhou,
A. M. Smith, A. K. Das, N. W. Hodson, R. F. Collins, R. V. Ulijn and J. E. Gough, Biomaterials, 2009, 30, 2523; H. Wang and Z. Yang, Nanoscale, 2012, 4, 5259; M. Nune, P. Kumaraswamy, U. M. Krishnan and S. Sethuraman, Curr. Protein Pept. Sci., 2013, 14, 70.

4 G. A. Silva, C. Czeisler, K. L. Niece, E. Beniash, D. A. Harrington, J. A. Kessler and S. I. Stupp, Science, 2004, 303, 1352; P. D. Tatman, E. G. Muhonen, S. T. Wickers, A. O. Gee, E.-S. Kim and D.-H. Kim, Biomater. Sci., 2016, 4, 543.

5 I. W. Hamley, Soft Matter, 2011, 7, 4122; D. M. Ryan and B. L. Nilsson, Polym. Chem., 2012, 3, 18; W. Y. Seow and C. A. E. Hauser, Mater. Today, 2014, 17, 381; S. Marchesan, L. Waddington, C. D. Easton, F. Kushkaki, K. M. McLean, J. S. Forsythe and P. G. Hartley, J. Bionanosci., 2013, 3, 21.

6 V. Jayawarna, M. Ali, T. A. Jowitt, A. F. Miller, A. Saiani, J. E. Gough and R. V. Ulijn, Adv. Mater., 2006, 18, 611; T. Liebmann, S. Rydholm, V. Akpe and H. Brismar, BMC Biotechnol., 2007, 7, 88; J. J. Panda, R. Dua, A. Mishra, B. Mittra and V. S. Chauhan, ACS Appl. Mater. Interfaces, 2012, 2, 2839.

7 R. Orbach, L. Adler-Abramovich, S. Zigerson, I. MironiHarpaz, D. Seliktar and E. Gazit, Biomacromolecules, 2009, 10, 2646; H. M. Wang, C. H. Yang, M. Tan, L. Wang, D. L. Kong and Z. M. Yang, Soft Matter, 2011, 7, 3897.

8 J. Makarević, M. Jokić, L. Frkanec, D. Katalenić and M. Žinić, Chem. Commun., 2002, 2238; S. Miljanić, L. Frkanec, Z. Meić and M. Žinić, Eur. J. Org. Chem., 2006, 1323; J. Makarević, M. Jokić, L. Frkanec, V. Čaplar, N. Šijaković Vujičić and M. Žinić, Beilstein J. Org. Chem., 2010, 6, 945; V. Čaplar, L. Frkanec, N. Šijaković Vujičić and M. Žinić, Chem. - Eur. J., 2010, 16, 3066; L. Frkanec, M. Jokić, J. Makarević, K. Wolsperger and M. Žinić, J. Am. Chem. Soc., 2002, 124, 9716; L. Frkanec and M. Žinić, Chem. Commun., 2010, 46, 522.

9 M. Reches and E. Gazit, Science, 2003, 300, 625; S. Deechongkit, E. T. Powers, S. L. You and J. W. Kelly, J. Am. Chem. Soc., 2005, 127, 8562; V. Jayawarna, M. Ali, T. A. Jowitt, A. F. Miller, A. Saiani, J. E. Gough and R. V. Ulijn, Adv. Mater., 2006, 18, 611; X. Yan, P. Zhu and J. Li, Chem. Soc. Rev., 2010, 39, 1877; M. Ma, Y. Kuang, Y. Gao, Y. Zhang, P. Gao and B. Xu, J. Am. Chem. Soc., 2010, 132, 2719.

10 D. E. Nitecki, B. Halpern and J. Westley, J. Org. Chem., 1968, 33, 864.

11 N. N. Liu, S. M. Zhao, J. F. Zhao, G. Z. Zeng, N. H. Tan and J. P. Liu, Tetrahedron Lett., 2014, 70, 6630.

12 T. Pospišil, M. Žinić and L. Frkanec, Czech Chem. Soc. Symp. Ser., 2016, 14, 126.

13 X. Du, J. Zhou, J. Shi and B. Xu, Chem. Rev., 2015, 115, 13165.

14 S. Motamed, M. P. Del Borgo, K. Kulkarni, N. Habila, K. Zhou, P. Perlmutter, J. S. Forsythe and M. I. Aguilar, Soft Matter, 2016, 12, 2243.

15 C. Yan and D. J. Pochan, Chem. Soc. Rev., 2010, 39, 3528; J. Raeburn, A. Z. Cardoso and D. J. Adams, Chem. Soc. Rev., 
2013, 42, 5143; L. Ying, Q. Meng, C. Yi and W. Wei, Sci. China: Phys., Mech. Astron., 2014, 57, 849.

16 L. Ouyang, R. Yao, X. Chen, J. Na and W. Sun, Biofabrication, 2015, 7, 015050; M. R. Ramezani, H. Naderi-Manesh and H. A. Rafieepour, Biocell, 2014, 38, 11.
17 G. Shaw, S. Morse, M. Ararat and F. L. Graham, FASEB J., 2002, 16, 869; Y. C. Lin, M. Boone, L. Meuris, I. Lemmens, N. Van Roy, A. Soete, J. Reumers, M. Moisse, S. Plaisance, R. Drmanac, J. Chen, F. Speleman, D. Lambrechts, Y. Van de Peer, J. Tavernier and N. Callewaert, Nat. Commun., 2014, 5, 4767. 